\title{
Baclofen into the lateral parabrachial nucleus induces hypertonic sodium chloride intake during cell dehydration
}

\author{
Everton H Kimura', Lisandra B De Oliveira², José V Menani ${ }^{3}$ and João C Callera ${ }^{1 *}$
}

\begin{abstract}
Background: Activation of $G A B A_{B}$ receptors with baclofen into the lateral parabrachial nucleus (LPBN) induces ingestion of water and $0.3 \mathrm{M} \mathrm{NaCl}$ in fluid replete rats. However, up to now, no study has investigated the effects of baclofen injected alone or combined with GABA $A_{B}$ receptor antagonist into the LPBN on water and $0.3 \mathrm{M} \mathrm{NaCl}$ intake in rats with increased plasma osmolarity (rats treated with an intragastric load of $2 \mathrm{M} \mathrm{NaCl}$ ). Male Wistar rats with stainless steel cannulas implanted bilaterally into the LPBN were used.

Results: In fluid replete rats, baclofen $(0.5 \mathrm{nmol} / 0.2 \mu \mathrm{l})$, bilaterally injected into the LPBN, induced ingestion of $0.3 \mathrm{M} \mathrm{NaCl}(14.3 \pm 4.1$ vs. saline: $0.2 \pm 0.2 \mathrm{ml} / 210 \mathrm{~min})$ and water $(7.1 \pm 2.9$ vs. saline: $0.6 \pm 0.5 \mathrm{ml} / 210 \mathrm{~min})$. In cell-dehydrated rats, bilateral injections of baclofen $(0.5$ and $1.0 \mathrm{nmol} / 0.2 \mu \mathrm{l})$ into the LPBN induced an increase of $0.3 \mathrm{M} \mathrm{NaCl}$ intake (15.6 \pm 5.7 and $21.5 \pm 3.5 \mathrm{ml} / 210 \mathrm{~min}$, respectively, vs. saline: $1.7 \pm 0.8 \mathrm{ml} / 210 \mathrm{~min})$ and an early inhibition of water intake ( $3.5 \pm 1.4$ and $6.7 \pm 2.1 \mathrm{ml} / 150 \mathrm{~min}$, respectively, vs. saline: $9.2 \pm 1.4 \mathrm{ml} / 150 \mathrm{~min})$. The pretreatment of the LPBN with 2-hydroxysaclofen (GABA antagonist, $5 \mathrm{nmol} / 0.2 \mu \mathrm{l})$ potentiated the effect of baclofen on $0.3 \mathrm{M} \mathrm{NaCl}$ intake in the first 90 min of test and did not modify the inhibition of water intake induced by baclofen in cell-dehydrated rats. Baclofen injected into the LPBN did not affect blood pressure and heart rate.
\end{abstract}

Conclusions: Thus, injection of baclofen into the LPBN in cell-dehydrated rats induced ingestion of $0.3 \mathrm{M} \mathrm{NaCl}$ and inhibition of water intake, suggesting that even in a hyperosmotic situation, the blockade of LPBN inhibitory mechanisms with baclofen is enough to drive rats to drink hypertonic $\mathrm{NaCl}$, an effect independent of changes in blood pressure.

Keywords: Baclofen, Dehydration, Sodium appetite, Thirst, Lateral parabrachial nucleus

\section{Background}

The lateral parabrachial nucleus (LPBN), is a pontine structure located dorsal to the superior cerebellar peduncle (SCP). The LPBN is reciprocally connected to different areas, such as area postrema (AP) and medial portion of the nucleus of the solitary tract (mNTS) in the hindbrain and forebrain areas, such as the paraventricular nucleus of the hypothalamus, central nucleus of amygdala and median preoptic nucleus [1-7]. Cells in the LPBN are activated after ingestion of $\mathrm{NaCl}$ solutions by dehydrated rats or by rats that received intragastric load of hypertonic

\footnotetext{
* Correspondence: jocaller@foa.unesp.br

'Department of Basic Sciences, School of Dentistry, UNESP - Univ. Estadual Paulista, Rodovia Marechal Rondom, km 527, Araçatuba, São Paulo 16018-805, Brazil

Full list of author information is available at the end of the article
}

$\mathrm{NaCl}$, suggesting that LPBN cells are activated by visceral or taste signals [8-10]. Therefore, the LPBN may convey signals that ascend from AP/mNTS to forebrain areas involved in the control of fluid and electrolyte balance.

Studies about the involvement of the LPBN in the control of fluid-electrolyte balance have investigated mainly the inhibitory mechanisms for water and $\mathrm{NaCl}$ intake and different neurotransmitters or receptors in the LPBN have been shown to be involved with these mechanisms. For example, bilateral injection of the serotonergic antagonist methysergide into the LPBN increased water and $0.3 \mathrm{M} \mathrm{NaCl}$ intake induced by different treatments [sodium depletion; subcutaneous treatment with the combination of furosemide (FURO) + captopril (CAP) and treatment with deoxycorticosterone (DOCA)], while injections of a serotonergic agonist (DOI) reduced these 
intakes [11-13]. Increase of FURO+CAP-induced sodium intake is also produced by the blockade of cholecystokinin $(\mathrm{CCK})$ receptors or activation of $\mathrm{GABA}_{\mathrm{A}}$ and $\mathrm{GABA}_{\mathrm{B}}$ receptors into the LPBN [14-16]. Therefore, in the LPBN, neurotransmitters like serotonin (5-HT) and CCK activate an inhibitory mechanism, while activation of GABAergic receptors in the LPBN is suggested to deactivate inhibitory mechanisms present in this area increasing water and $0.3 \mathrm{M} \mathrm{NaCl}$ intake.

The LPBN is also related to the inhibition of sodium intake by increased plasma osmolarity. Previous studies have shown that the blockade of LPBN inhibitory mechanisms by injections of methysergide or moxonidine combined with an increase in plasma osmolarity (intragastric load of $2 \mathrm{M} \mathrm{NaCl}$ ) induced an unexpected ingestion of hypertonic $\mathrm{NaCl}[17,18]$, a clear paradox considering that $2 \mathrm{M} \mathrm{NaCl}$ load usually suppresses sodium appetite [19]. In addition, a previous study showed that activation of $\mathrm{GABA}_{\mathrm{A}}$ receptors into the LPBN induced $0.3 \mathrm{M} \mathrm{NaCl}$ intake in cell-dehydrated rats, suggesting that the increase in plasma osmolarity subsequent to $\mathrm{NaCl}$ ingestion does not appear to prevent further salt intake when $\mathrm{GABA}_{\mathrm{A}}$ receptors in the $\mathrm{LPBN}$ are activated [20].

The $\gamma$-aminobutyric acid (GABA) is the most important inhibitory neurotransmitter in the mammalian central nervous system [21,22]. GABA receptors can be classified into two structurally and pharmacologically distinct subclasses: $\mathrm{GABA}_{\mathrm{A}}$ and $\mathrm{GABA}_{\mathrm{B}}[23,24]$. Activation of $\mathrm{GABA}_{\mathrm{A}}$ receptors leads to opening of the channel and the conductance of $\mathrm{Cl}^{-}$ions and this effect may be antagonized by bicuculline [25]. $\mathrm{GABA}_{\mathrm{B}}$ receptors are metabotropic, $G$ protein-coupled receptors that mediate presynaptic and postsynaptic inhibition by reductions in calcium conductance or increases in potassium conductance $[24,26] . \mathrm{GABA}_{\mathrm{B}}$ receptors are activated by baclofen and 2-hydroxysaclofen antagonizes these receptors [26,27].

A dense plexus of GABA-immunoreactive varicosities has been shown throughout the parabrachial nucleus $(\mathrm{PBN})$ and Kolliker fuse (KF) complex [28]. Both $\mathrm{GABA}_{\mathrm{A}}$ and $\mathrm{GABA}_{\mathrm{B}}$ receptors are present in $\operatorname{LPBN}[29,30]$ and a previous study showed that baclofen injected into LPBN induced ingestion of $0.3 \mathrm{M} \mathrm{NaCl}$ and water in fluid replete rats [31]. In addition, injections of baclofen into the LPBN increased $0.3 \mathrm{M} \mathrm{NaCl}$ and water intake by rats injected subcutaneously with the diuretic furosemide combined with the angiotensin converting enzyme inhibitor captopril [16].

Considering the possibility that baclofen deactivates the inhibitory mechanisms and increases $0.3 \mathrm{M} \mathrm{NaCl}$ intake in cell-dehydrated rats like that produced by $\mathrm{GABA}_{\mathrm{A}}$ receptor activation in the LPBN, in the present study, we investigated the effects of bilateral injections of baclofen alone or combined with the $\mathrm{GABA}_{\mathrm{B}}$ receptor antagonist 2-hydroxysaclofen into the LPBN on $0.3 \mathrm{M}$ $\mathrm{NaCl}$ and water intake in rats with increased plasma osmolarity and compared the responses with the effects of baclofen into the LPBN on sodium intake in fluid replete rats that received no pre-treatment. In addition, possible changes in cardiovascular responses to baclofen injected into the LPBN in cell-dehydrated rats were also investigated. Intragastric load of $2 \mathrm{M} \mathrm{NaCl}$ produces cell dehydration by increasing plasma osmolality and sodium concentration and also reduces plasma renin activity [32].

\section{Materials and methods}

\section{Animals}

Male Wistar rats weighing 290-310 g were used. The animals were housed in individual stainless steel cages with free access to normal sodium diet (Guabi Rat Chow, Paulinia, SP, Brazil), water and $0.3 \mathrm{M} \mathrm{NaCl}$ solution. The position of the bottles containing water and $0.3 \mathrm{M} \mathrm{NaCl}$ was rotated daily to avoid place preference. Room temperature was maintained at $23 \pm 2^{\circ} \mathrm{C}$ and humidity at $55 \pm 10 \%$ in a 12:12 light-dark cycle with light onset at 07:30 AM. The Institutional Ethics Committee on Animal Care and Use of the School of Dentistry, Araçatuba-UNESP approved the experimental protocols used in the present study (Proc. CEEA No. 057/03) and followed the recommendations of the Brazilian College of Animal Experimentation (COBEA). The procedures were in compliance with the National Institutes of Health Guide for the Care and Use of Laboratory Animals (NIH publication No. 80-23, 1996, USA). All efforts were made to minimize animal discomfort and the number of animals used.

\section{Cerebral cannulas}

Rats were anesthetized with ketamine $(80 \mathrm{mg} / \mathrm{kg}$ of body weight, Agener União, Embu-Guaçu, SP, Brazil) combined with xylazine $(7 \mathrm{mg} / \mathrm{kg}$ of body weight, Agener União, Embu-Guaçu, SP, Brazil ) and placed in a Kopf stereotaxic instrument (Kopf, Tujunga, CA, USA). The skull was leveled between bregma and lambda. Bilateral stainless steel 23-gauge cannulas were implanted in direction to the LPBN using the following coordinates: 9.4 $\mathrm{mm}$ caudal to bregma, $2.2 \mathrm{~mm}$ lateral to the midline, and $3.9 \mathrm{~mm}$ below the dura mater. The tips of the cannulas were put into place at a point $2 \mathrm{~mm}$ above each LPBN. The cannulas were fixed to the cranium using dental acrylic resin and jeweler screws. A 30-gauge metal obturator filled the cannulas between tests. The experiments began 5 days later when the animals had fully recovered from the surgery.

\section{Injections into the LPBN}

Bilateral injections into the LPBN were made using 5- $\mu \mathrm{l}$ Hamilton syringe connected by polyethylene tubing (PE- 
10) to 30-gauge injection cannula. At the time of testing, the obturators were removed and the injection cannula (2 $\mathrm{mm}$ longer than the guide cannula) was carefully inserted into the guide cannula, and manual injection was initiated $15 \mathrm{~s}$ later. For bilateral injections, the first injection was initially performed in one side, the needle was withdrawn and repositioned on the contralateral side, and then the second injection was made. Therefore, injections were made $\sim 1$ min apart. The injection volume into the LPBN was $0.2 \mu \mathrm{l}$ in each site. The obturators were replaced after the injections, and the rats were put back into their cages.

\section{Drugs}

The drugs injected into the LPBN were $( \pm)$-baclofen and 2-hydroxysaclofen purchased from Sigma-Aldrich (Saint Louis, MO, USA) and were dissolved in $0.15 \mathrm{M} \mathrm{NaCl}$. The doses of baclofen and 2-hydroxysaclofen were chosen based on a previous study [31]. Doses of baclofen produce a long-lasting action (at least for three hours) when injected into the LPBN. The dose of 2-hydroxysaclofen used was an effective dose that blocks $\mathrm{GABA}_{\mathrm{B}}$ receptors into LPBN as showed previously [31].

\section{Water and $0.3 \mathrm{M} \mathrm{NaCl}$ intake}

The rats were tested in their home cages. In addition to water and food pellets, rats had access to $0.3 \mathrm{M} \mathrm{NaCl}$ for at least 5 days before the experiments began. The effects of baclofen were tested under three different experimental conditions: 1) In the same group of rats $(n=9)$, we evaluated if baclofen affect water and $0.3 \mathrm{M}$ $\mathrm{NaCl}$ intake in rats that received no pre-treatment (fluid replete rats) and after intragastric load of $2 \mathrm{M} \mathrm{NaCl}$ (cell-dehydrated condition). First, fluid replete rats received injections of baclofen $(0.5 \mathrm{nmol} / 0.2 \mu \mathrm{l})$ or saline into the LPBN and $15 \mathrm{~min}$ later rats were given water and $0.3 \mathrm{M} \mathrm{NaCl}$ in graduated $(0.1 \mathrm{ml}$ divisions $)$ glass burettes. Cumulative water and $0.3 \mathrm{M} \mathrm{NaCl}$ intake was measured at each 30 min time interval in the next 210 min after the access to water and sodium solution. The same group of animals, received an intragastric load of 2 $\mathrm{M} \mathrm{NaCl}$, to induce cellular dehydration. Forty-five minutes later, half of the group received injections of baclofen $(0.5 \mathrm{nmol} / 0.2 \mu \mathrm{l})$, and the other half received saline into the LPBN and $15 \mathrm{~min}$ later rats had free access to both water and $0.3 \mathrm{M} \mathrm{NaCl}$ (two-bottle test). Cumulative water and $0.3 \mathrm{M} \mathrm{NaCl}$ intake was recorded at each 30 min time interval in the next $210 \mathrm{~min}$ after the access to water and sodium solution. The same procedure was repeated in a second experimental session performed 3 days later in a counterbalanced design. All tests began between 13:00 p.m. and 16:00 p.m.

2) In another group of cell-dehydrated rats $(n=11)$, the effects of two different doses of baclofen (0.5 and 1.0 $\mathrm{nmol} / 0.2 \mu \mathrm{l})$ injected into the LPBN on water and $0.3 \mathrm{M}$
$\mathrm{NaCl}$ intake were tested. Rats received an intragastric load of $2 \mathrm{M} \mathrm{NaCl}$. Forty-five minutes later, half of the group received baclofen $(0.5$ or $1.0 \mathrm{nmol} / 0.2 \mu \mathrm{l})$, and the other half received saline injections into the LPBN. The same procedure was repeated in a second experimental session performed 3 days later in a counterbalanced design. Fifteen minutes after LPBN injections, the animals had free access to both water and $0.3 \mathrm{M} \mathrm{NaCl}$. Cumulative water and $0.3 \mathrm{M} \mathrm{NaCl}$ intake was recorded at each 30, 60, 90, 120,180 , and $210 \mathrm{~min}$ after the access to water and sodium solution. All tests began between 13:00 p.m. and 16:00 p.m.

3) To test a possible participation of $\mathrm{GABA}_{B}$ receptors in the effects of baclofen, another group of rats $(n=6)$ received an intragastric load of $2 \mathrm{M} \mathrm{NaCl} 45 \mathrm{~min}$ before bilateral injections of baclofen $(0.5 \mathrm{nmol} / 0.2 \mu \mathrm{l})$ or saline into the LPBN, and cumulative water and $0.3 \mathrm{M} \mathrm{NaCl}$ intake was measured at each $30 \mathrm{~min}$ in the next 210 min, starting $15 \mathrm{~min}$ after the injections of baclofen or saline into the LPBN. This group of rats also received bilateral injections of 2-hydroxysaclofen $(5 \mathrm{nmol} / 0.2 \mu \mathrm{l})$ or saline into the LPBN, $15 \mathrm{~min}$ before baclofen or saline injections. This group of rats was submitted to four tests. In each test the group was divided in two subgroups that received different combinations of treatments into the LPBN. The sequence of the combinations of treatments into the LPBN in each rat in different tests was randomized, and at the end of the tests each rat received all the combinations of treatments into the LPBN. All tests began between 13:00 p.m. and 16:00 p.m.

\section{Arterial pressure and heart rate recordings}

Mean arterial pressure (MAP) and heart rate (HR) were recorded in unanesthetized rats. One day before recording, the rats were anesthetized with ketamine $(80 \mathrm{mg} / \mathrm{kg}$ of body weight $)+$ xylazine (7 mg/kg of body weight), a polyethylene tubing (PE 10 connected to a PE 50) was inserted into the abdominal aorta through the femoral artery for arterial pressure recording. The cannula was guided subcutaneously and exteriorized at the back of the rat. On the next day, the cannula was connected to a P23 Db pressure transducer (Statham Gould) coupled to a pre-amplifier (model ETH-200 Bridge Bio Amplifier, CB Sciences) connected to a Powerlab computer recording system (Powerlab 8SP, ADInstruments) to record MAP and HR. The animals received an intragastric $2 \mathrm{M}$ $\mathrm{NaCl}$ load and forty-five minutes after this, one group of rats was tested for the effects of baclofen $(1.0 \mathrm{nmol} / 0.2$ $\mu \mathrm{l})$ and another group for the effects of saline injected into the LPBN on MAP and HR. MAP and HR were recorded for the next 180 minutes after injections into LPBN and the maximum changes were analyzed. During MAP and HR recordings, the rats did not have access to water, $0.3 \mathrm{M} \mathrm{NaCl}$ and food. 


\section{Histology}

On completion of the experiments, the animals received bilateral injections of $0.2 \mu \mathrm{l}$ of $2 \%$ Evans blue dye into the LPBN. Then, they were deeply anesthetized with sodium thiopental (80 mg/kg of body weight) and perfused transcardially with saline followed by $10 \%$ formalin. The brains were removed, fixed in $10 \%$ formalin, frozen, cut in $60 \mu \mathrm{m}$ serial coronal sections, stained with Giemsa, and analyzed by light microscopy to confirm the injection sites into the LPBN.

\section{Statistical analysis}

The results are reported as means \pm S.E.M. Water and $0.3 \mathrm{M} \mathrm{NaCl}$ intake were analyzed by two-way analysis of variance (ANOVA) with repeated measures for both factors (treatments and times), followed by Newman-Keuls post hoc test. Significance was set at $P<0.05$. The software used to analyze the data was SigmaStat for Windows, version 2.03 from SPSS Inc.

\section{Results}

\section{Histological analysis}

Similar to previous reports $[16,20,31]$, the LPBN injection sites were centered in the central lateral and dorsolateral portions of the LPBN. Figure 1 shows the typical LPBN injection sites. Injections reaching the ventral lateral and external lateral portions, as well as the Kolliker-Fuse nucleus, were observed in some rats and the results from these rats were included in the analysis. In some rats, injections also spread to the brachium (superior cerebellar peduncle), or slightly ventral to this structure, reaching the dorsal portions of the medial parabrachial nucleus $(\mathrm{MPBN})$ uni- or bilaterally. There was no difference in the effects whether injections were restricted to the LPBN or also spread to brachium and dorsal portions of MPBN.

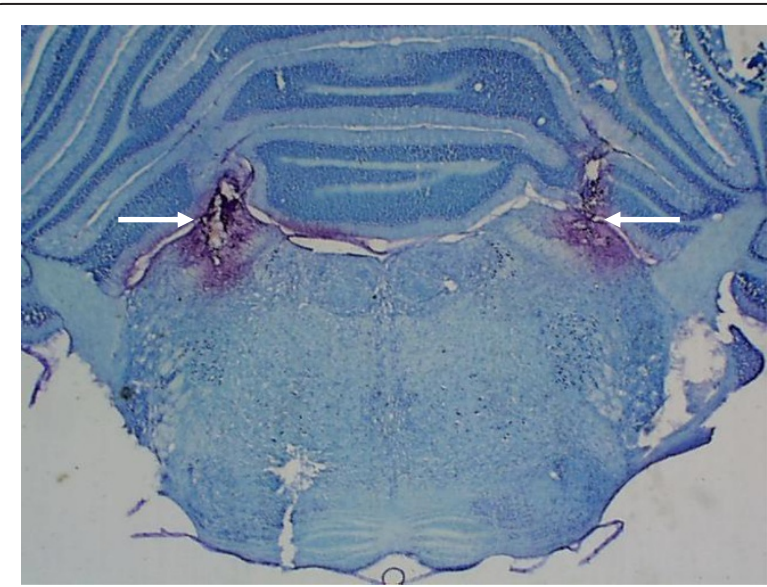

Figure 1 Photomicrograph showing the sites of injections into the LPBN (arrows).
Effects of bilateral injections of baclofen into the LPBN on water and $0.3 \mathrm{M} \mathrm{NaCl}$ intake in fluid replete and celldehydrated rats

Bilateral injection of baclofen $(0.5 \mathrm{nmol} / 0.2 \mu \mathrm{l}, \mathrm{n}=9)$ into the LPBN in fluid replete rats induced $0.3 \mathrm{M} \mathrm{NaCl}$ and water intake from 150 to $210 \mathrm{~min}$ of test (Figure 2A, C). In rats treated with an intragastric load of $2 \mathrm{M} \mathrm{NaCl}$, baclofen injected into the LPBN increased $0.3 \mathrm{M} \mathrm{NaCl}$ intake from 150 to $210 \mathrm{~min}$ of test (Figure 2A, B) and reduced water intake from 30 to $150 \mathrm{~min}$ of test (Figure 2C, D). ANOVA showed significant interaction between treatments and time for $0.3 \mathrm{M} \mathrm{NaCl}$ intake $[F(18,144)=4.3 ; P<0.001$, Figure $2 \mathrm{~A}, \mathrm{~B}]$ and water intake $[F(18,144)=3.3 ; P<0.001$, Figure $2 \mathrm{C}, \mathrm{D}$ ) in fluid replete rats and cell-dehydrated rats that received baclofen into the LPBN.

A hypotonic mixture of water and $0.3 \mathrm{M} \mathrm{NaCl}$ was ingested throughout the experimental session when fluid replete rats received saline in the LPBN. On an average, the rats ingested $0.2 \pm 0.2 \mathrm{ml}$ of $0.3 \mathrm{M} \mathrm{NaCl}$ versus $0.6 \pm$ $0.5 \mathrm{ml}$ of water in $210 \mathrm{~min}$, which yielded a solution of approximately $0.09 \mathrm{M}$. However, fluid replete rats that received baclofen into the LPBN ingested $14.3 \pm 4.1 \mathrm{ml}$ of $0.3 \mathrm{M} \mathrm{NaCl}$ and $7.1 \pm 2.9 \mathrm{ml}$ of water in $210 \mathrm{~min}$, which results in a hypertonic solution $(0.2 \mathrm{M})$ (Figure $2 \mathrm{~A}, \mathrm{C}$ ).

After intragastric load of $2 \mathrm{M} \mathrm{NaCl}$, bilateral LPBN injections of baclofen $(0.5$ and $1.0 \mathrm{nmol} / 0.2 \mu \mathrm{l})$ into the LPBN induced ingestion of $0.3 \mathrm{M} \mathrm{NaCl}$ from 120 to 210 min of test (Figure 3A, B), and an inhibition of water intake from 30 to $120 \mathrm{~min}$ of test (Figure 3C, D). There were no significant differences in $0.3 \mathrm{M} \mathrm{NaCl}$ intake $[F(1,10)=1.1 ; \mathrm{P}>0.05$, Figure $3 \mathrm{~A}, \mathrm{~B}]$ and water intake $[F(1,10)=2.8 ; \mathrm{P}>0.05$, Figure $3 \mathrm{C}, \mathrm{D}]$, in celldehydrated rats treated with different doses of baclofen $(0.5$ and $1.0 \mathrm{nmol} / 0.2 \mu \mathrm{l})$ into the LPBN.

Cell-dehydrated rats $(n=11)$ that received saline in the LPBN ingested $1.7 \pm 0.8 \mathrm{ml}$ of $0.3 \mathrm{M} \mathrm{NaCl}$ and $9.2 \pm 1.4$ $\mathrm{ml}$ of water in $210 \mathrm{~min}$. Considering the total intake, the result is a hypotonic solution (nearly $0.05 \mathrm{M}$ ). Celldehydrated rats treated with baclofen $(0.5 \mathrm{nmol} / 0.2 \mu \mathrm{l})$ into the LPBN ingested $17.9 \pm 4.2 \mathrm{ml}$ of $0.3 \mathrm{M} \mathrm{NaCl}$ and $5.2 \pm 1.9 \mathrm{ml}$ of water in $210 \mathrm{~min}$, which results in a hypertonic solution (nearly $0.23 \mathrm{M}$ ). Cell-dehydrated rats treated with baclofen $(1.0 \mathrm{nmol} / 0.2 \mu \mathrm{l})$ into the LPBN also ingested a hypertonic solution $(0.21 \mathrm{M})$.

\section{Effects of the combination of 2-hydroxysaclofen and baclofen into the LPBN on water and $0.3 \mathrm{M} \mathrm{NaCl}$ intake in cell-dehydrated rats}

ANOVA showed significant differences among treatments for $0.3 \mathrm{M} \mathrm{NaCl}$ intake by cell-dehydrated rats that received saline or 2-hydroxysaclofen combined with saline or baclofen into the $\operatorname{LPBN}[F(3,15)=9.5 ; \mathrm{P}<0.05$, Figure $4 \mathrm{~A}, \mathrm{~B}]$. There was significant interaction between treatments 

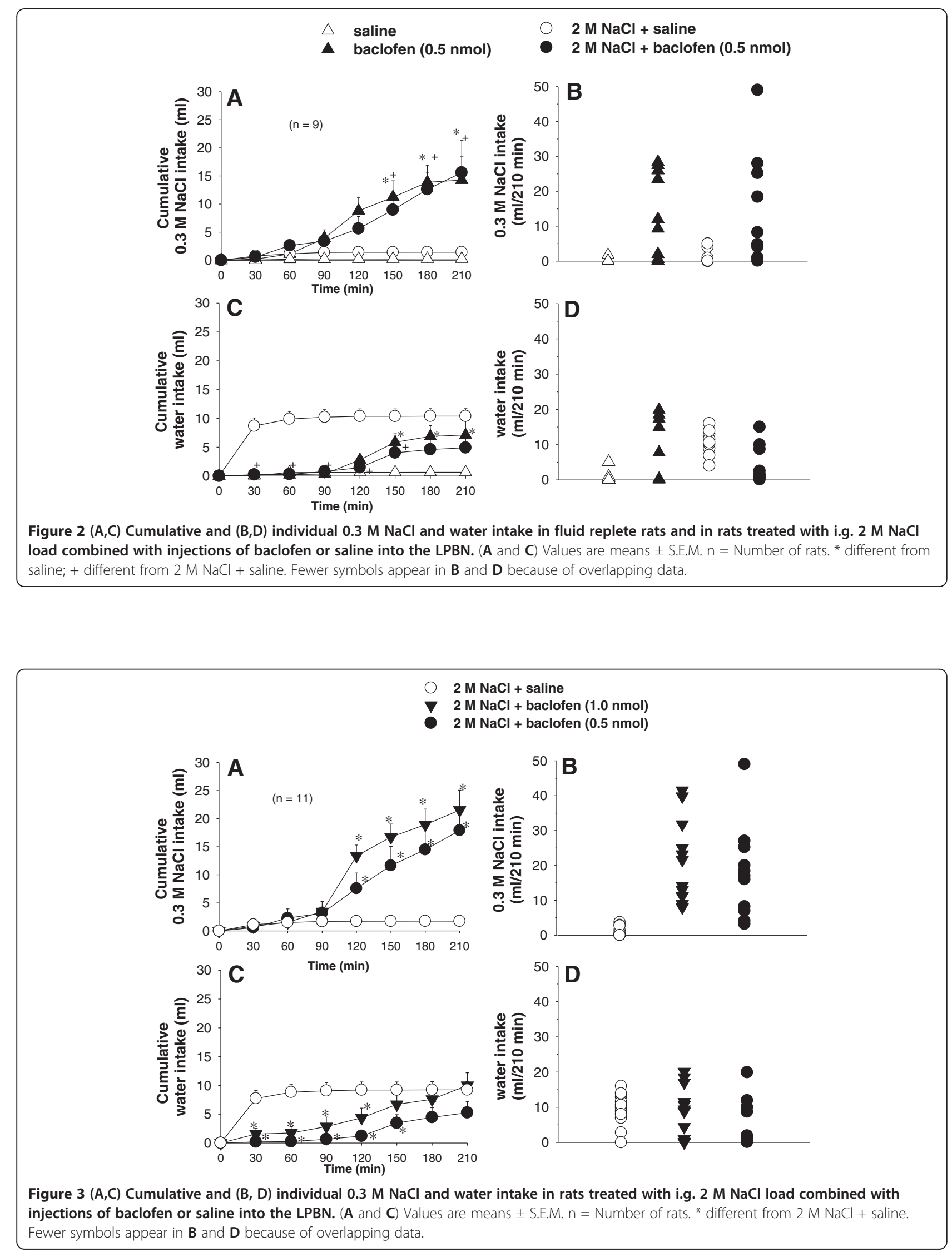
and times for water intake $[\mathrm{F}(18,90)=2.2 ; \mathrm{P}<0.05$, Figure 4C, D].

Bilateral injections of baclofen after pretreatment with saline into the LPBN induced $0.3 \mathrm{M} \mathrm{NaCl}$ intake from 150 to 210 min of the test with $\mathrm{P}$ values ranging from $\mathrm{P}<0.005$ at 150 min to $\mathrm{P}<0.001$ at 180 and $210 \mathrm{~min}$ (Figure 4A). Baclofen induced an early inhibitory effect on water intake in the first $150 \mathrm{~min}$ of the test with $\mathrm{P}$ values ranging from $\mathrm{P}<0.05$ at $30 \mathrm{~min}$ to $\mathrm{P}<0.001$ at 60 to $150 \mathrm{~min}$ (Figure 4C, D). Previous injections of 2-hydroxysaclofen ( $5 \mathrm{nmol} / 0.2 \mu \mathrm{l}$ ) into the LPBN increased $0.3 \mathrm{M} \mathrm{NaCl}$ intake induced by baclofen in the first 90 minutes of test $(8.6 \pm 3.6$; $12.0 \pm 4.3$ vs, baclofen: $0.01 \pm 0.01 ; 1.7 \pm 0.7 \mathrm{ml}$; respectively for 60 and $90 \mathrm{~min}$; $\mathrm{P}<0.005$, Figure $4 \mathrm{~A}$ ), and did not modify $0.3 \mathrm{M} \mathrm{NaCl}$ intake induced by baclofen injected in the same area from 120 to 210 min of test $(P>0.1)$.

Water intake after 2-hydroxysaclofen + baclofen into the LPBN did not differ from saline + baclofen into the LPBN $(\mathrm{P}>0.5$ for all times tested, Figure $4 \mathrm{C}, \mathrm{D})$. After saline + 2-hydroxysaclofen injection into the LPBN, water or $0.3 \mathrm{M}$ $\mathrm{NaCl}$ intake did not differ from control test with saline injections into the LPBN ( $>0.1$ at any of the times studied).

Effects of bilateral injections of baclofen into the LPBN on arterial pressure and $\mathrm{HR}$ in cell-dehydrated rats

Bilateral injections of baclofen $(1 \mathrm{nmol} / 0.2 \mu \mathrm{l})$ into the LPBN in normotensive rats (basal MAP: $120 \pm 4.2$
$\mathrm{mmHg}$ and basal HR: $363 \pm 6.6$ beats per min, bpm), previously treated with intragastric load of $2 \mathrm{M} \mathrm{NaCl}$, did not affect changes in MAP $(3.7 \pm 3.8$ vs. saline: $4.9 \pm$ $1.5 \mathrm{mmHg}, \mathrm{n}=7)$, [F $(1,6)=0.1 ; \mathrm{P}>0.05]$ neither changes in $\mathrm{HR}(1.5 \pm 12.7$ vs. saline: $6.7 \pm 13.7 \mathrm{bpm})$, $[\mathrm{F}(1,6)=0.5 ; \mathrm{P}>0.05]$.

\section{Specificity of injections into the LPBN to produce the} effects on water and $0.3 \mathrm{M} \mathrm{NaCl}$ intake in cell-dehydrated rats

The specificity of the LPBN as the site where baclofen produced the effects on water and $0.3 \mathrm{M} \mathrm{NaCl}$ intake in cell-dehydrated rats was confirmed by results from rats in which the injections did not reach the LPBN (misplaced injections). Bilateral injections of baclofen $(0.5 \mathrm{nmol})$, 2-hydroxysaclofen (5 nmol) or 2-hydroxysaclofen combined with baclofen outside the LPBN produced no effect on $0.3 \mathrm{M} \mathrm{NaCl}$ or on water intake (Table 1). ANOVA showed no significant difference among treatments for $0.3 \mathrm{M} \mathrm{NaCl}$ intake $[F(3,15)=0.54 ; P>0.05]$ or water intake $[F(3,15)=1.69 ; P>0.05]$ by celldehydrated rats that received injections in sites outside the LPBN (Table 1). Injections outside the LPBN reached different sites; the majority were dorsal or caudal to the LPBN, although a few were ventral or rostral to the LPBN.

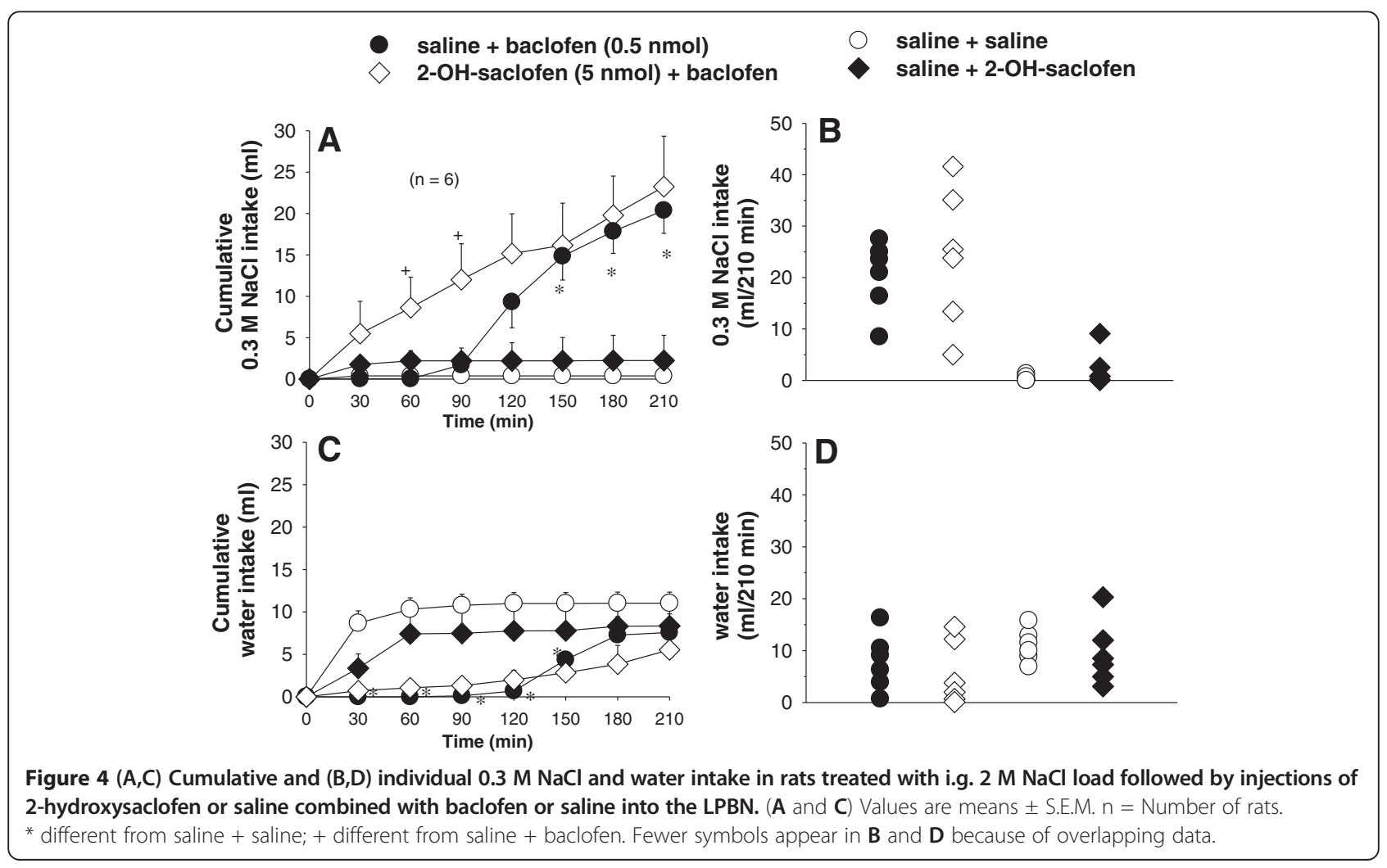


Table 1 Ingestion of water and $0.3 \mathrm{M} \mathrm{NaCl}$ by celldehydrated rats treated with saline or 2-hydroxysaclofen combined with saline or baclofen in sites outside the LPBN (misplaced injections)

\begin{tabular}{lccc}
\hline Treatments & $\boldsymbol{n}$ & $\begin{array}{c}\mathbf{0 . 3} \mathbf{~ M ~ N a C l} \text { intake } \\
(\mathbf{m l} / \mathbf{2 1 0} \mathbf{~ m i n})\end{array}$ & $\begin{array}{c}\text { Water intake } \\
(\mathbf{m l} / \mathbf{2 1 0} \mathbf{~ m i n})\end{array}$ \\
\hline Saline + saline & 6 & $2.8 \pm 1.3$ & $8.9 \pm 1.4$ \\
\hline Saline + baclofen $(0.5 \mathrm{nmol})$ & 6 & $3.1 \pm 1.7$ & $6.5 \pm 2.8$ \\
\hline 2-hydroxysaclofen $(5 \mathrm{nmol})+$ & & \\
\hline baclofen & 6 & $3.9 \pm 1.8$ & $7.9 \pm 2.8$ \\
\hline 2-hydroxysaclofen $(5 \mathrm{nmol})+$ & & \\
\hline saline & 6 & $3.6 \pm 2.3$ & $8.3 \pm 2.2$ \\
\hline
\end{tabular}

Values are means \pm S.E.M.; n, number of rats.

\section{Discussion}

In the present study, we showed that bilateral injections of baclofen into the LPBN induced both $0.3 \mathrm{M} \mathrm{NaCl}$ and water intake in rats that received no pre-treatment. Bilateral injections of baclofen into the LPBN induced ingestion of $0.3 \mathrm{M} \mathrm{NaCl}$ (from 120 to $210 \mathrm{~min}$ of test) and inhibited the large increases in water intake in hyperosmotic cell-dehydrated rats. At the end of 210 min of test, fluid replete rats and cell-dehydrated rats ingested a similar amount of $0.3 \mathrm{M} \mathrm{NaCl}$ after administration of baclofen into the LPBN despite of the hyperosmolality, hypernatremia, reduction of plasma renin activity and normovolemia present in celldehydrated rats [32]. Results from rats with misplaced injections confirmed that baclofen produces effects on water and $0.3 \mathrm{M} \mathrm{NaCl}$ intake if injected specifically in the LPBN and not into the surrounding areas.

In a recent study [20], the authors also showed that the blockade of LPBN inhibitory mechanisms by injections of muscimol in this area also induced $0.3 \mathrm{M} \mathrm{NaCl}$ intake in fluid replete rats and in rats treated with intragastric $2 \mathrm{M} \mathrm{NaCl}$ load, suggesting that the increase in plasma osmolarity subsequent to $\mathrm{NaCl}$ ingestion does not appear to prevent further salt intake when $\mathrm{GABA}_{\mathrm{A}}$ receptors in the LPBN are activated.

Therefore, the present results suggest that baclofen injected into the LPBN induces ingestion of $0.3 \mathrm{M} \mathrm{NaCl}$ irrespective of the initial physiological state of the rats. A possible conclusion from these results is that it is not necessary to activate the excitatory mechanisms by baclofen into the LPBN for $\mathrm{NaCl}$ intake, which differs from the mechanisms that have been proposed to explain increased sodium intake after the blockade of LPBN inhibitory mechanisms [11-13].

Peripheral administration of baclofen reduce water deprivation-induced water intake and reduce water intake in rats pretreated with a hypertonic solution of $\mathrm{NaCl}[33,34]$. The results obtained in this study on the effects of baclofen injected into the LPBN on water intake in dehydrated rats are therefore similar to those previously reported [33]. Ebenezer et al. [34] also demonstrated that systemic administration of baclofen had no effects on water intake in fluid replete rats. Interestingly, in the present study was demonstrated that bilateral injection of baclofen into the LPBN induced water and $0.3 \mathrm{M} \mathrm{NaCl}$ intake (150 - $210 \mathrm{~min}$ of test) in a twobottle test in fluid replete rats. Recently [31], we showed that injections of baclofen into the LPBN induced no water intake if only water was available. As indicated by the present results, ingestion of water usually increased after injections of baclofen into the LPBN when fluid replete rats simultaneously ingested $0.3 \mathrm{M} \mathrm{NaCl}$. In spite of the simultaneous ingestion of water, this intake is not enough to compensate for the increased osmolarity produced by the ingestion of hypertonic $\mathrm{NaCl}$. The fluid ingested (water and $0.3 \mathrm{M} \mathrm{NaCl}$ ), after injections of baclofen into the LPBN, was hypertonic during most of the test. Therefore, it seems that the increase in plasma osmolarity due to the ingestion of hypertonic $\mathrm{NaCl}$ may be reinforcing the effect of baclofen on sodium intake instead of inducing water intake.

We suggest that the effect of baclofen injected into the LPBN on water and sodium intake was due to a direct effect of baclofen on the LPBN. Callera et al. [15] demonstrated that bicuculline injected into the LPBN 60 min after muscimol strongly reduced the effects of muscimol on $0.3 \mathrm{M} \mathrm{NaCl}$ and water intake, suggesting that muscimol and probably baclofen is acting at this moment releasing water and sodium intake. On the contrary, baclofen into the LPBN reduced water intake in cell-dehydrated rats (30-150 min of test). Therefore, the effects on $0.3 \mathrm{M} \mathrm{NaCl}$ and water intake were due to baclofen facilitating the actions on GABA receptors.

The natriorexigenic effect of baclofen might be a secondary effect of baclofen injected into the LPBN, and reductions in blood pressure or increases in renal excretion would be one possibility. However, baclofen injected into the LPBN produces non-significant effects on blood pressure and renal excretion in fluid replete rats and cell-dehydrated rats [31, present data], suggesting that the natriorexigenic response to baclofen injected into the LPBN is not secondary to cardiovascular responses or increased renal excretion. It seems that injections of baclofen, similar to the injections of muscimol into the LPBN [20], completely block the action of all the inhibitory mechanisms present in the LPBN, which combined with any residual facilitatory signal still present as the one produced by normal levels of ANG II may facilitate water and especially $\mathrm{NaCl}$ intake.

Recently [16], we showed that pretreatment of the $\mathrm{LPBN}$ with bilateral injections of the nonpeptide $\mathrm{AT}_{1}$ receptor antagonist losartan reduced $0.3 \mathrm{M} \mathrm{NaCl}$ and water intake caused by baclofen injected into the same 
site in fluid replete rats, as well as the increase in water and $0.3 \mathrm{M} \mathrm{NaCl}$ produced by baclofen injected bilaterally into the $\mathrm{LPBN}$ in FURO+CAP-treated rats, suggesting that angiotensinergic mechanisms in the LPBN are essential for the dipsogenic and natriorexigenic responses induced by the blockade of LPBN neurons with baclofen in fluid replete rats or $\mathrm{FURO+CAP-treated} \mathrm{rats.} \mathrm{It} \mathrm{is}$ possible that ANG II acting on $\mathrm{AT}_{1}$ receptors in hyperosmotic cell-dehydrated rats is not sufficient to facilitate water intake produced by baclofen in the LPBN. The ingestion of $0.3 \mathrm{M} \mathrm{NaCl}$ after baclofen injections into the LPBN takes at least $2 \mathrm{~h}$ to start, which is a time enough for changes in the levels of ANG II that acting in the LPBN may intensify the effects of baclofen on LPBN neurons, a step necessary for the release of sodium intake. More studies are necessary to investigate the effects of previous injection of $\mathrm{AT}_{1}$ receptor antagonist on water and sodium intake induced by baclofen injected into the LPBN in hyperosmotic cell-dehydrated rats.

The present study also showed that blockade of the $\mathrm{GABA}_{\mathrm{B}}$ receptors with 2-hydroxysaclofen alone into the LPBN did not affect sodium intake in cell-dehydrated rats, suggesting that GABAergic mechanisms in the LPBN do not tonically inhibit or facilitate $0.3 \mathrm{M} \mathrm{NaCl}$ intake [15,20,31]. In addition, previous blockade of the $\mathrm{GABA}_{\mathrm{B}}$ receptors with 2-hydroxysaclofen injected into the LPBN produced no effect on late $0.3 \mathrm{M} \mathrm{NaCl}$ intake and inhibition of water intake induced by baclofen injected in the same area. Although still not completely clear, the blockade of $\mathrm{GABA}_{\mathrm{B}}$ receptor potentiated the natriorexigenic effect of baclofen in the first $90 \mathrm{~min}$ of the test. An involvement of $\mathrm{GABA}_{\mathrm{A}}$ and $\mathrm{GABA}_{\mathrm{B}}$ receptors in the natriorexigenic effect of baclofen has previously been reported [31]. The natriorexigenic effect of baclofen injected into the LPBN in fluid replete rats was reduced by the pre-treatment with the $\mathrm{GABA}_{\mathrm{B}}$ receptor antagonist 2-hydroxysaclofen or by the $\mathrm{GABA}_{\mathrm{A}}$ receptor antagonist bicuculline injected into the same area. Perhaps, the activation of $\mathrm{GABA}_{\mathrm{B}}$ receptors by baclofen injected into the LPBN together with a baseline activation of $\mathrm{GABA}_{\mathrm{A}}$ receptors by endogenous GABA produces a sufficient inhibition of LPBN mechanisms to release sodium intake. Or instead of endogenous GABA, a nonspecific activation of a limited number of $G_{A B A}$ receptors by baclofen together with the activation of $\mathrm{GABA}_{\mathrm{B}}$ receptors in the LPBN might inhibit the LPBN mechanisms releasing $\mathrm{NaCl}$ intake. In both cases, although only the activation of $\mathrm{GABA}_{\mathrm{B}}$ receptors produces no sodium intake, the activation of $G_{A B A}$ receptors in the LPBN may facilitate the effects of $\mathrm{GABA}_{\mathrm{A}}$ receptor activation on sodium intake. An involvement of $\mathrm{GABA}_{\mathrm{A}}$ receptors on baclofen effects was already reported. The inhibition of food intake by intraperitoneal administration of baclofen was abolished by previous treatment with bicuculline, suggesting a possible involvement of $\mathrm{GABA}_{\mathrm{A}}$ receptors in the effects of baclofen [35].

Thus, the present results show that the blockade of LPBN mechanisms with baclofen induces hypertonic $\mathrm{NaCl}$ intake and reduces water intake in cell-dehydrated rats and induces hypertonic $\mathrm{NaCl}$ intake and reduces urinary sodium excretion and diuresis in fluid replete rats [31], all responses consistent with an action of LPBN mechanisms against body fluid volume expansion as previously proposed for the serotonergic mechanism in the LPBN [36]. Thus, further studies in rats submitted to intracellular dehydration are needed to test the effects of GABA receptors of the LPBN on behavioral and renal functions that induce to volume expansion.

\section{Conclusion}

In conclusion, the results of our experiments show that fluid replete rats or hyperosmotic cell-dehydrated rats ingest similar amounts of $0.3 \mathrm{M} \mathrm{NaCl}$ after bilateral injections of baclofen into the LPBN. This observation means that, after the blockade of LPBN inhibitory mechanisms with baclofen, hypertonic $\mathrm{NaCl}$ intake occurs independent of whether plasma renin levels are normal or reduced and independent of changes in blood pressure.

\begin{abstract}
Abbreviations
(ANG II): Angiotensin II; (AP): Area postrema; (bpm): Beats per minute; (b. wt.): Body weight; (CAP): Captopril; (CCK): Cholecystokinin; (CRF): Corticotrophin release factor; (DOCA): Deoxycorticosterone acetate; (DOI): 2,5-dimetoxy-4-iodoamphetamine hydrobromide; (FURO): Furosemide; (GABA): Gamma-aminobutyric acid; (HR): Heart rate; (i.g.): Intragastric; (LPBN): Lateral parabrachial nucleus; (MAP): Mean arterial pressure; $(\mathrm{NaCl})$ : Sodium chloride; (OVLT): Organum vasculosum of the lamina terminalis; (SCP): Superior cerebellar peduncle.
\end{abstract}

\section{Competing interests}

The authors declare that they have no competing interests.

\section{Authors' contributions}

All the authors have made a substantial contribution to the conception and design of the study (EHK, LBO, JVM and JCC), the acquisition, analysis and interpretation of the data (EHK and JCC) and the drafting and revision of the article (LBO, JVM, and JCC). All the authors read and approved the final manuscript.

\section{Acknowledgements}

The authors thank Arnaldo Cesar dos Santos for animal care. This research was supported by Brazilian public funding from Sao Paulo State Research Foundation (FAPESP) and Fundação para o Desenvolvimento da UNESP (FUNDUNESP). Everton $\mathrm{H}$. Kimura was recipient of graduate fellowships from FAPESP (São Paulo State Research Foundation, grant 2003/10592-0).

\section{Author details}

${ }^{1}$ Department of Basic Sciences, School of Dentistry, UNESP - Univ. Estadual Paulista, Rodovia Marechal Rondom, km 527, Araçatuba, São Paulo 16018-805, Brazil. '2Department of Biological Sciences, DECBI-NUPEB, Federal University of Ouro Preto, UFOP, Ouro Preto, Minas Gerais, Brazil. ${ }^{3}$ Department of Physiology and Pathology, School of Dentistry, UNESP, Araraquara, São Paulo, Brazil.

Received: 7 December 2012 Accepted: 23 April 2013

Published: 3 May 2013 


\section{References}

1. Norgren R: The central organization of the gustatory and visceral systems in the nucleus of the solitary tract. In Brain Mechanisms of Sensation. Edited by Katsuki Y, Norgren R, Sato M. New York: Wiley; 1981:143-160

2. Ciriello J, Laurence D, Pittman QJ: Electrophysiological identification of neurons in the parabrachial nucleus projecting directly to the hypothalamus in the rat. Brain Res 1984, 322:388-392.

3. Fulwiler CE, Saper CB: Subnuclear organization of the efferent connections of the parabrachial nucleus in the rat. Brain Res Rev 1984, 7:229-259.

4. Shapiro RE, Miselis RR: The central neural connections of the area postrema of the rat. J Comp Neurol 1985, 234:344-364.

5. Herbert H, Moga MM, Saper CB: Connections of the parabrachial nucleus to the solitary tract and the medullary reticular formation in the rat. J Comp Neurol 1990, 293:540-580.

6. Jhamandas JH, Petrov T, Harris KH, Vu T, Krukoff TL: Parabrachial nucleus projection to the amygdala in the rat: electrophysiological and anatomical observations. Brain Res Bull 1996, 39:115-126.

7. Krukoff TL, Harris KH, Jhamandas JH: Efferent projections from the parabrachial nucleus demonstrated with the anterograde tracer Phaseolus vulgaris leucoaglutinin. Brain Res Bull 1993, 30:163-172.

8. Kobashi M, Ichikawa H, Sugimoto T, Adachi A: Response of neurons in the solitary tract nucleus, area postrema and lateral parabrachial nucleus to gastric load of hypertonic saline. Neurosci Lett 1993, 158:47-50.

9. Yamamoto T, Shimura T, Sako N, Sakai N, Tanimizu T, Wakisaka S: cFos expression in the parabrachial nucleus after ingestion of sodium chloride in the rat. Neuroreport 1993, 4:1223-1226.

10. Franchini $L F$, Vivas $L$ : Distribution of Fos immunoreactivity in rat brain after sodium comsumption induced by peritoneal dialysis. Am J Physiol 1999, 276:R1180-R1187.

11. Menani JV, Thunhorst RL, Johnson AK: Lateral parabrachial nucleus and serotonergic mechanisms in the control of salt appetite in rats. Am J Physiol 1996, 270:R162-R168.

12. Menani JV, De Luca LA Jr, Johnson AK: Lateral parabrachial nucleus serotonergic mechanisms and salt appetite induced by sodium depletion. Am J Physiol 1998, 274:R555-R560.

13. De Gobbi JIF, De Luca LA Jr, Menani JV: Serotonergic mechanisms of the lateral parabrachial nucleus on DOCA-induced sodium intake. Brain Res 2000, 880:131-138.

14. De Gobbi JIF, De Luca LA Jr, Johnson AK, Menani JV: Interaction of serotonin and cholecystokinin in the lateral parabrachial nucleus to control sodium intake. Am J Physiol 2001, 280:R1301-R1307.

15. Callera JC, De Oliveira LB, Barbosa SP, Colombari DAS, De Luca Jr LA, Menani JV: $\mathrm{GABA}_{\mathrm{A}}$ receptor activation in the lateral parabrachial nucleus induces water and hypertonic $\mathrm{NaCl}$ intake. Neuroscience 2005, 134:725-735.

16. Da Silva CZC, Menani JV, Callera JC: Natriorexigenic effect of baclofen is reduced by $\mathrm{AT}_{1}$ receptor blockade in the lateral parabrachial nucleus. Brain Res Bull 2011, 86:348-354.

17. De Luca Jr LA, Barbosa SP, Menani JV: Brain serotonin blockade and paradoxical salt intake in rats. Neuroscience 2003, 121:1055-1061.

18. Andrade CAF, De Luca LA Jr, Colombari DSA, Menani JV: Alpha2-adrenergic activation in the lateral parabrachial nucleus induces $\mathrm{NaCl}$ intake under conditions of systemic hyperosmolarity. Neuroscience 2006, 142:21-28.

19. Blackburn RE, Samson WK, Fulton RJ, Stricker EM, Verbalis JG: Central oxytocin and ANP receptors mediate osmotic inhibition of salt appetite in rats. Am J Physiol 1995, 269:R245-R251.

20. Kimura EH, De Oliveira LB, Colombari DSA, De Luca LA Jr, Menani JV, Callera JC: Sodium intake by hyperosmotic rats treated with a $G A B A_{A}$ receptor agonist into the lateral parabrachial nucleus. Brain Res 2008, 1190:86-93.

21. Sivilotti L, Nistri A: GABA receptor mechanism in the central nervous system. Prog Neurobiol 1991, 36:35-92.

22. Araki T, Kiyama $H$, Tohyama $M$ : The $G A B A_{A}$ receptor gamma 1 subunit is expressed by distinct neuronal populations. Mol Brain Res 1992, 15:121-132.

23. Bowery NG, Hudson AL, Price $G W: G A B A_{A}$ and $G A B A_{B}$ receptor site distribution in the rat central nervous system. Neuroscience 1987, 20:365-383.

24. Bowery NG: $G A B A_{B}$ receptors and their significance in mammalian pharmacology. Trends Pharmacol Sci 1989, 10:401-407.

25. Akaiki N, Hattori K, Oomura Y, Carpenter DO: Bicuculline and picrotoxinin block $\mathrm{Y}$-aminobutyric acid-gated $\mathrm{Cl}^{-}$conductance by different mechanisms. Experientia 1985, 41:70-71.
26. Kerr DIB, Ong J: GABA B receptors. J Pharmacol Ther 1995, 67:187-246.

27. Kerr DIB, Ong J, Johnston GAR, Abbenante J, Prager RH: 2-Hydroxysaclofen: an improved antagonist at central and peripheral $G A B A_{B}$ receptors. Neurosci Lett 1988, 92:92-96.

28. Guthmann A, Fritschy JM, Ottersen OP, Torp R, Herbert H: GABA, GABA transporters, GABA(A) receptor subunits, and GAD mRNAs in the rat parabrachial and kolliker-Fuse nuclei. J Comp Neurol 1998, 19:229-243.

29. Christie MJ, North RA: Agonists at mu-opioid, $\mathbf{M}_{2}$-muscarinic and GABA receptors increase the same potassium conductance in rat lateral parabrachial neurones. Br J Pharmacol 1988, 95:896-902.

30. Van Nieuwenhuijzen PS, Mcgregor IS, Hunt GE: The distribution of $Y$ hydroxybutyrate-induced Fos expression in rat brain: Comparison with baclofen. Neuroscience 2009, 158:441-455.

31. De Oliveira LB, Kimura EH, Callera JC, De Luca LA Jr, Colombari DSA, Menani $\mathrm{JV}$ : Baclofen into the lateral parabrachial nucleus induces hypertonic $\mathrm{NaCl}$ and sucrose intake in rats. Neuroscience 2011, 183:160-170.

32. Pereira DT, Vendramini RC, David RB, Nozaki PN, Menani JV, De Luca LA Jr: Isotonic NaCl intake by cell-dehydrated rats. Physiol Behav 2002, 76:501-505.

33. Houston AJ, Wong JCL, Ebenezer IS: Effects of the $G_{A B A}$ receptor agonist baclofen on primary drinking in rats. Eur J Pharmacol 2012, 674:327-331.

34. Ebenezer IS, Houston AJ, Crook TJ: Systemic administration of baclofen inhibits water intake in rats. Gen Pharmacol 1992, 23:375-379.

35. Zarrindast MR, Hosseini-Nia T, Allah-Maddadi S: Food intake suppressant effect of baclofen in rats. Gen Pharmacol 1989, 20:701-703.

36. Margatho LO, Giusti-Paiva A, Menani J, Elias LLK, Vivas LM, AntunesRodrigues J: Serotonergic mechanisms of the lateral parabrachial nucleus in renal and hormonal responses to isotonic blood volume expansion. Am J Physiol 2007, 292:R1190-R1197.

doi:10.1186/1744-9081-9-17

Cite this article as: Kimura et al:: Baclofen into the lateral parabrachial nucleus induces hypertonic sodium chloride intake during cell dehydration. Behavioral and Brain Functions 2013 9:17.

\section{Submit your next manuscript to BioMed Central and take full advantage of:}

- Convenient online submission

- Thorough peer review

- No space constraints or color figure charges

- Immediate publication on acceptance

- Inclusion in PubMed, CAS, Scopus and Google Scholar

- Research which is freely available for redistribution 